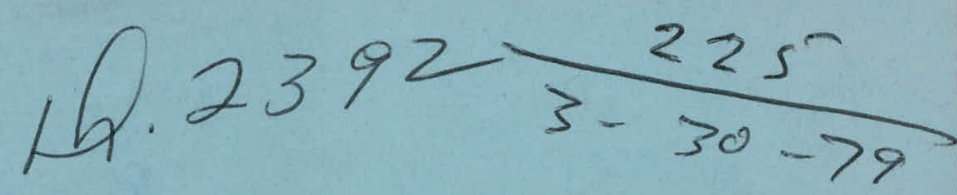

\title{
THE 1978 BREEDING-BIRD CENSUSES
}

\author{
GILBERT S. RAYNOR
}

September 1978

ATMOSPHERIC SCIENCES DIVISION DEPARTMENT OF ENERGY AND ENVIRONMENT

BROOKHAVEN NATIONAL LABORATORY ASSOCIATED UNIVERSITIES, INC. 


\section{DISCLAIMER}

This report was prepared as an account of work sponsored by an agency of the United States Government. Neither the United States Government nor any agency Thereof, nor any of their employees, makes any warranty, express or implied, or assumes any legal liability or responsibility for the accuracy, completeness, or usefulness of any information, apparatus, product, or process disclosed, or represents that its use would not infringe privately owned rights. Reference herein to any specific commercial product, process, or service by trade name, trademark, manufacturer, or otherwise does not necessarily constitute or imply its endorsement, recommendation, or favoring by the United States Government or any agency thereof. The views and opinions of authors expressed herein do not necessarily state or reflect those of the United States Government or any agency thereof. 


\section{DISCLAIMER}

Portions of this document may be illegible in electronic image products. Images are produced from the best available original document. 
BNL 50933

UC-11

(Environmental Control Technology

and Earth Sciences - TID-4500)

\title{
THE 1978 BREEDING-BIRD CENSUSES
}

\author{
GILBERT S. RAYNOR
}

September 1978

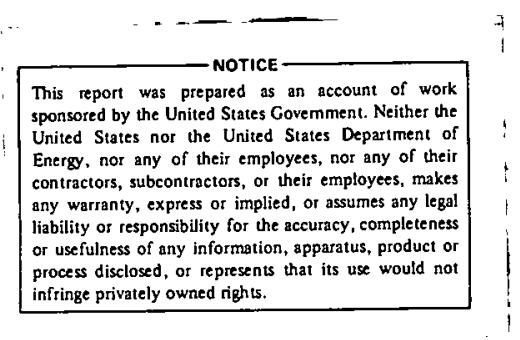

\author{
ATMOSPHERIC SCIENCES DIVISION \\ DEPARTMENT OF ENERGY AND ENVIRONMENT
}

\section{BROOKHAVEN NATIONAL LABORATORY \\ UPTON, NEW YORK 11973}




\section{NOTICE}

This report was prepared as an account of work sponsored by the United States Government. Neither the United States nor the United States Department of Energy (DOE), nor any of their employees, nor any of their contractors, subcontractors, or their employees, makes any warranty, express or implied, or assumes any legal liability or responsibility for the accuracy, completeness or usefulness of any information, apparatus, product or process disclosed, or. represents that its use would not infringe privately owned rights.

Printed in the United States of America Available from

National Technical Information Service U.S. Department of Commerce 5285 Port Royal Road Springfield, VA 22161

Price: Printed Copy $\$ 4.00$; Microfiche $\$ 3.00$ 
As part of a program to characterize the plant and animal life of the Laboratory site and surrounding areas, the two breeding-bird censuses taken in 1977 were repeated in 1978. Five observers made thirteen census trips to both the BNL and Westhampton plots. A decrease in Rufous-sided Towhees occurred on both plotr, but other changes were small and not considered significant. 
The two breeding-bird censuses initiated in 1977 and reported in BNL 50775 were repeated in 19:78: The same four: observers: (James H. Clinton, David L. Larsen, Gilbert S. Raynor, and John J. Ruscica) shared: coverage of both: plots. They were joined by Robert: Adamo who is not: affiliated with BNL and worked only on the Westhampton plot.

No significant change occurred in the vegetation of either plot. Two minor plant species not found in 1977 were noted, the Bird's-foot Violet (Viola pedata) and Pink-Lady's Slipper (Cypripedium acaule) at Westhampton and the Lady's Slipper- at' BNL:

A description of the census trips with weather conditions is given in Table 1. One additional evening visit was made. at. BNL to listen for nocturnal species. Because of the length of time needed. for surveying and marking the plots, coverage was not. started until late May 1977 and the early part of the breeding season was missed. Coverage in $1977^{\circ}$ continued until mid-July at Westhampton and late July at BNL, but the trips after early July contributed little useful data. Therefore, coverage in 1978 was started in late April and terminated in early July with most frequent trips at the height of the breeding season in June. 'At BNL, man-hours totaled 33 in 1978 as compared with 28 in 1977. At Westhampton, man-hours totaled 32 in 1977 and 28 in 1978. The decrease was caused by omitting one census trip for which the record was 1ost. The numbers on the stakes were painted in: April prior to the census period.

The species composition and density of territorial males on the BNL plot are given in Table 2 and on the Westhampton plot. in Table. 3. Because of better data and more experience, the best estimates of the number of territories are given instead of ranges as in 1977. At BNL, one Towhee nest was found. A pair of Black-capped Chickadees was observed attempting to excavate 
a nesthole on an early visit but the wood proved too hard and the attempt was abandoned. Visitors included Yellow-billed Cuckoo, Eastern Wood Pewee, Wood Thrush, Common Yellowthroat, Common Grackle, Brown-headed Cowbird, and Cardinal.

lrends caunnot be discerned with only two years of data but changes in number of males and species composition were relatively minor. The decrease in Towhees is believed real. No new species occurred as a territorial male. Two of the three species recorded in 1977. but not in 1978 were considered visitors in 1978. The Wh1te-breasted Nuthatch was not present.

Several typographical errors were discovered in Table 7 of BNL 50775. The total of territorial males hsould have been 46.5 - 60.5 instead of $82-96$. In the columns No. $/ \mathrm{km}^{2}$ and No./100 Acres, the six consecutive values of 4 and 11 should be interchanged. However, the column totals are correct.

At Westhampton, one Towhee nest was found. Visitors included Marsh Hawk, Mourning Dove, Tree Swallow, Barn Swallow, Purple Martin, Blue Jay, Blackcapped Chickadee, and Common Grackle.

Compared with 1977, the number of Towhees decreased at Westhampton as we1.1 as at BNL. The apparent increase in Prairie Warblers and Field Sparrows is probably due to better coverage early in the season. Other changes are not. significant.

The census will be continued in future years. 
Table 1

Description of 1978 Census "Trips

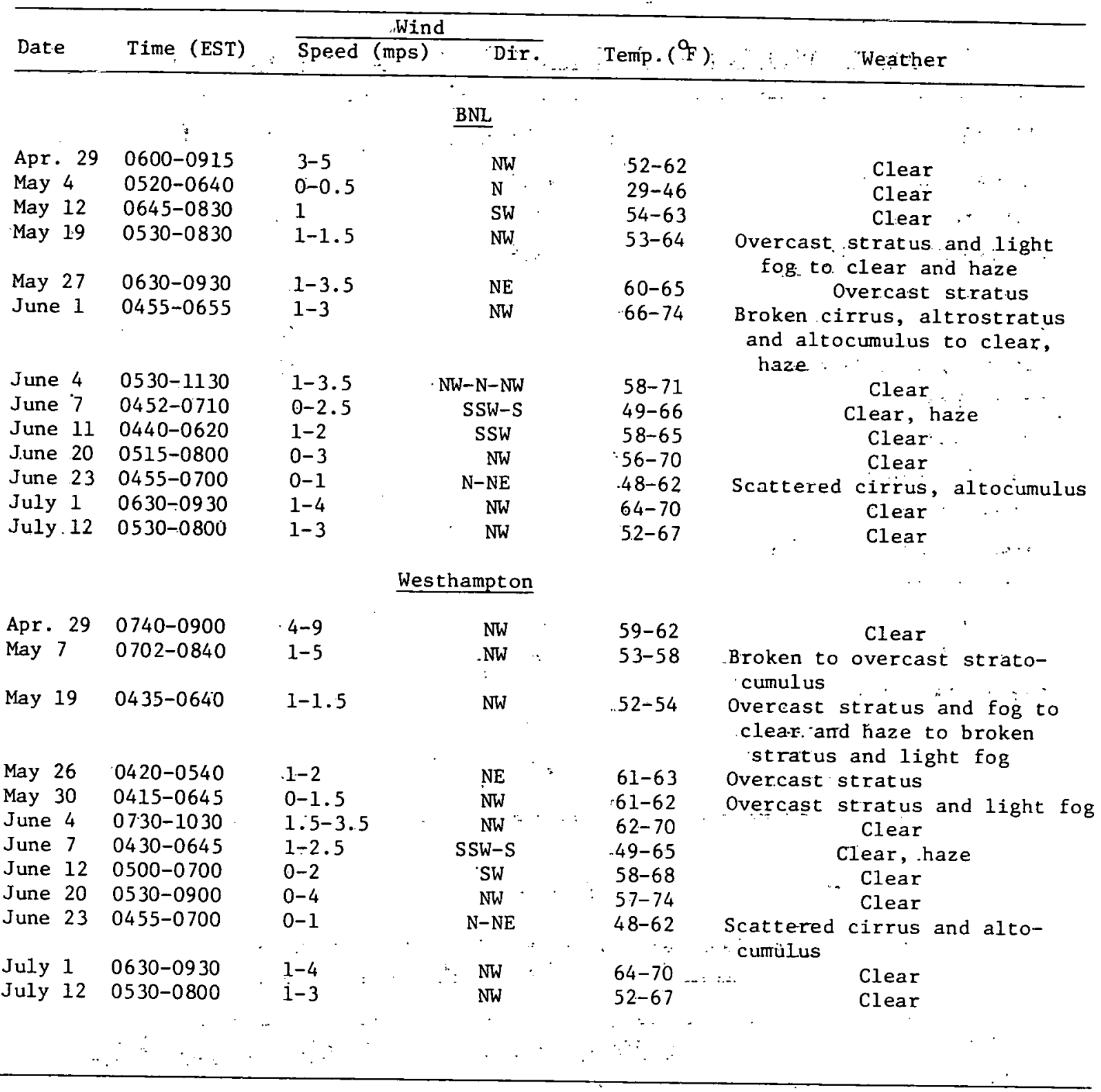


Table 2.

Species Composition and. Density of Territorial Males on BNL Plot

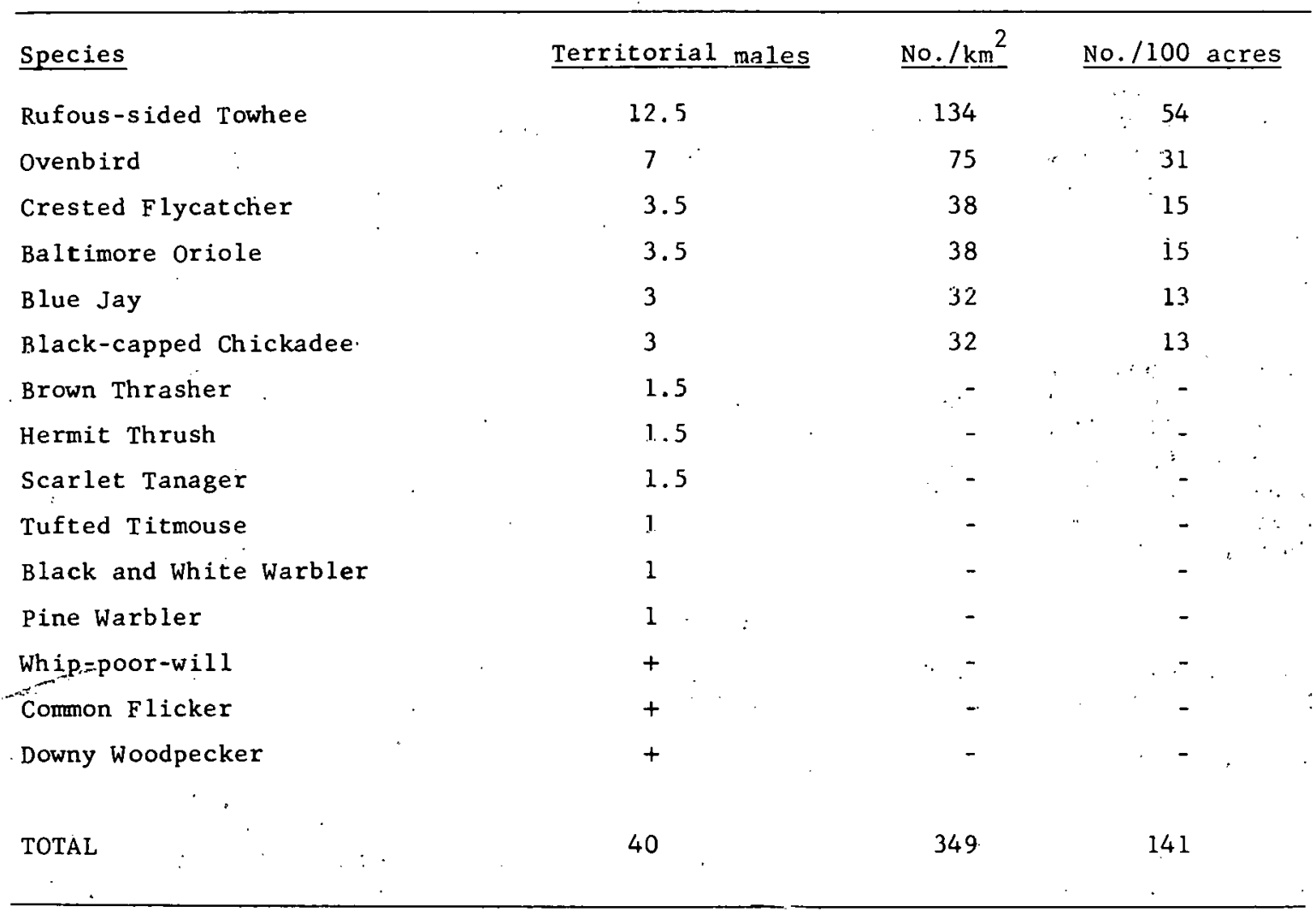

Table 3

Species Composition and Densicy of Territorial Males on Westhampton Plot

\begin{tabular}{lcccc}
\hline Species & Territorialmales & & No. $/ \mathrm{km}^{2}$ & No. $/ 100$ acres \\
\cline { 2 - 4 } Prairie Warbler & 14.5 & 11.5 & 150 & 61 \\
Rufous-sided Towhee & 6 & 62 & 48 \\
Field Sparrow & 2 & 21. & 8 \\
Brown Thrasher & + & - & - \\
Mockingbird & + & & - \\
Common Yellowthroat & 34 & 352 & 142 \\
Total & & & \\
\hline
\end{tabular}


